\title{
Significance of cervical length and cervical gland area in cervical maturation
}

\section{Channaveeregowda Savitha*, Venkatesh Jnanashree Arpitha, Rangaiah Nagarathnamma}

Department of Obstetrics and Gynaecology, Rajarajeswari Medical College and Hospital, Kambipura, Mysore Road, Kengeri, Bangalore-560074, Karnataka, India

Received: 02 June 2016

Accepted: 01 July 2016

\section{* Correspondence:}

Dr. Channaveeregowda Savitha,

E-mail: savitha_824@yahoo.com

Copyright: (C) the author(s), publisher and licensee Medip Academy. This is an open-access article distributed under the terms of the Creative Commons Attribution Non-Commercial License, which permits unrestricted non-commercial use, distribution, and reproduction in any medium, provided the original work is properly cited.

\section{ABSTRACT}

Background: The traditional method of predicting whether an induced labor will result in successful vaginal delivery is based on pre-induction favorability of cervix as assessed by bishop score. Currently assessment of cervical maturation by sonographically at term in induction of labor is most accurate and highly reproducible compared to Bishop score. Shortening of cervix and non-detection of cervical gland area (CGA) could correspond to cervical maturation.

Methods: This study was carried out in a tertiary care teaching institute in Karnataka. 180 pregnant women at or beyond 37weeks who were planned for induction, Bishop score assessment of cervix and cervical assessment by ultrasound such as cervical length (CL) and cervical gland area was done one day prior to induction. Induction was with $0.5 \mathrm{mg}$ PGE2gel. Maximum 3 inductions were carried out over a period of $24 \mathrm{hrs}$. Primary outcome of the study was the onset of active labor.

Results: Amongst 160 pregnant women who were induced (20 women were excluded has they underwent LSCS for some other reasons during latent phase) cervical length by sonography $<2 \mathrm{~cm}$ were 14 none had failed induction. Cervical gland area $<2 \mathrm{~mm}$ (35) and absent (30) none had failed induction. Amongst the 180 pregnant women who were induced CGA was absent in 42 all had Bishop score $>4$. Cervical length $<2 \mathrm{~cm}$ in 14 all had Bishop score $>4$. Conclusions: Sonographically detected cervical gland area and cervical length was evaluated in predicting response to induction. Absent CGA and CL $<2 \mathrm{~cm}$ was associated with greater incidence of successful labor induction. This results show the CL and CGA has significant role in predicting outcome of labor.

Keywords: Cervical length, Cervical gland area, Bishop score

\section{INTRODUCTION}

The transcendent objective of obstetrics is that every pregnancy should culminate in "healthy baby and healthy mother". The most important factor to achieve in a vaginal delivery is a favourable cervix. Towards term and in preparation of labor, the cervix undergoes certain changes which include collagen breakdown and rearrangement of collagen fibrils, alteration in the relative amounts of various glycosaminoglycan's which is intensely hydrophilic and decrease in dermatan sulfate. ${ }^{1}$ The success of induction of labor is largely dependent on the state of cervix and parity.
The traditional method of predicting whether an induced labor will result in successful vaginal delivery is based on the pre induction favourability of the cervix as assessed by bishop score. However this assessment is subjective and several studies have shown poor predictive value, also effacement is subjective and varies considerably among examiner. ${ }^{2}$ Currently, the measurement of cervical length is used sonographically for the assessment of the cervix during pregnancy. Shortening of the cervix represent cervical maturation, trans-vaginal sonography can represent more accurate measurement of cervix than digital because supra-vaginal position of cervix comprises about 50 percent cervical length which is 
difficult to assess digitally and highly reproducible. ${ }^{3}$ In the past few years publications have highlighted the importance of morphological ultrasonographic marker that could directly reflect cervical maturation named as the "cervical gland area".,24-26

Non detection of cervical gland area could correspond to the beginning of the uterine cervix maturation. ${ }^{4,25}$ Transvaginal evaluation of cervix is useful in predicting successful labor induction (i.e. initiation of active labor represented by cervical dilatation of more than $3 \mathrm{~cm}$ in the presence of uterine contraction). Hence in our study we propose to compare pre-induction cervical length and cervical gland area by trans-vaginal ultrasound with bishop score as a predictor of successful induction of labor.

Induction of labor is non-spontaneous initiation of uterine contraction that results in progressive cervical effacement, dialatation of cervix and descent of presenting part at vaginal delivery of healthy baby. ${ }^{6}$ Failed induction- there is no universally accepted definition for failed induction. It should perhaps be reserved for those cases where the cervix does not dialate beyond $3 \mathrm{~cm}$ despite adequate and appropriate oxytocic stimulation. ${ }^{6}$ Kumaran A et al diagnose it when a patient who is induced does not enter the active labour despite of adequate management for 12 hours. ${ }^{7}$

Trans-vaginal sonography is an effective method for the study of the uterine cervix during pregnancy since it permits to assess the cervical morphology and biometry in detail with a high degree of reliability. In sagittal plane the cervix is seen as a cylindrical moderately echogenic structure with a central canal. The anterior and posterior lips of the cervix can sometimes be outlined as it protrudes in to the vagina which is at right angles to it.

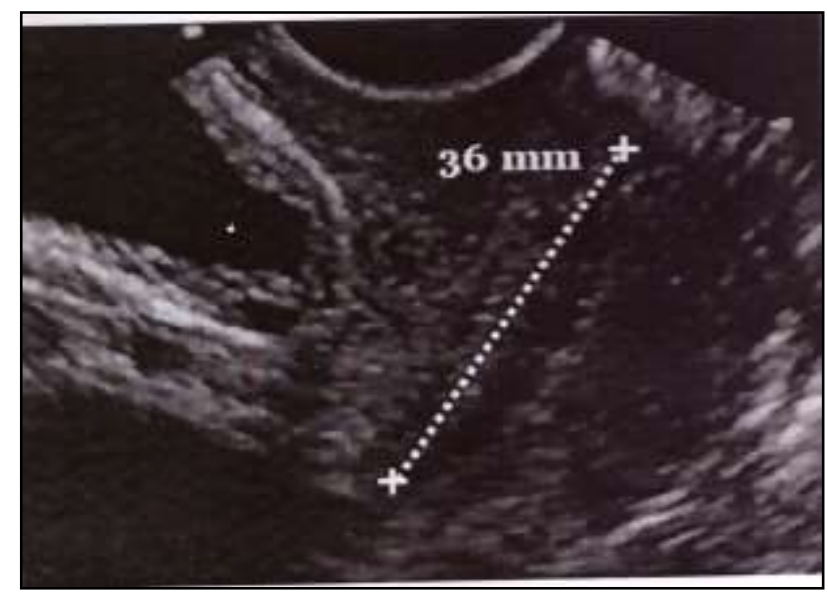

Figure 1: Ultrasonographic image that shows a longitudinal section of cervix.

In pregnant state, the internal os is identified with amniotic membrane or presenting part jus superior to it. The cervical canal is surrounded by hyper echoic or hypo echoic zone identified as cervical gland area, which is identified as a region with echo texture different from the uterine cervix stroma located in the periphery of the cervical canal and would correspond to the endocervical crypts area. This zone is consistently seen until 31 weeks of gestation and disappears as pregnancy advances. The lack of detection of cervical gland area which is associated with cervical ripening, maybe another sonographic clue for predicting labor. ${ }^{8}$

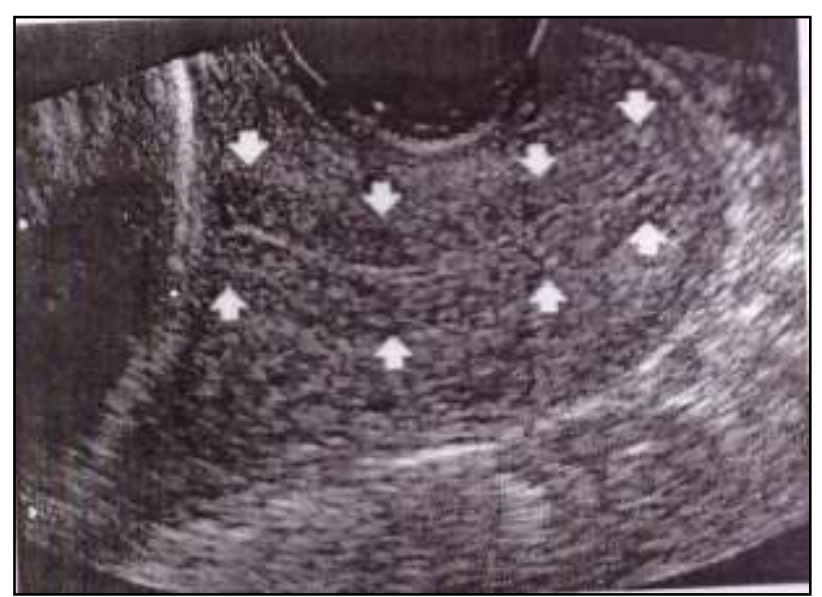

Figure 2: Ultrasonographic image that shows a sagittal section of uterine cervix. The full arrows points to a transition between the cervical gland area (hypoechoic aspect) and the cervical stroma.

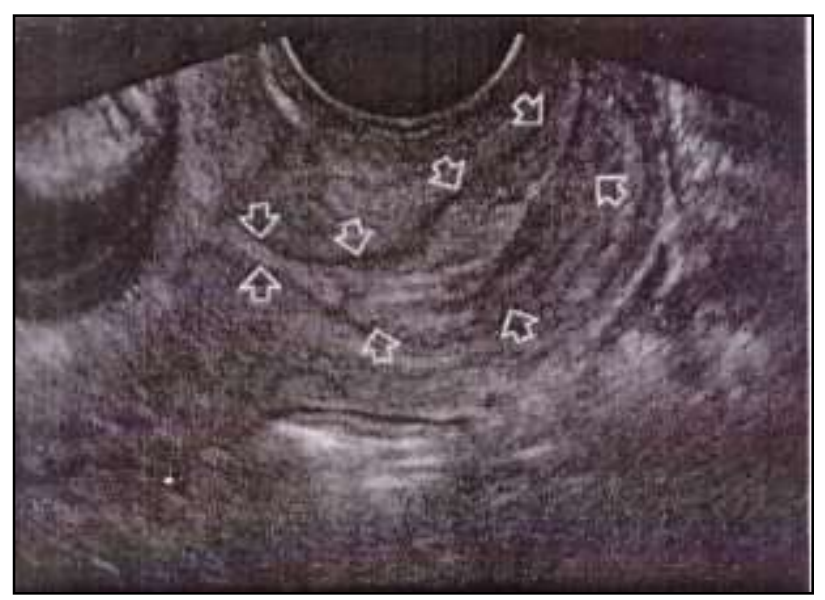

Figure 3: Another ultrasonographic image that shows a sagittal section of uterine cervix. The empty arrows points to a transition between the cervical gland area (hyperechoic) and the cervical stroma.

\section{METHODS}

A study was carried out on 180 pregnant ladies admitted in labor room for induction of labor. Women with singleton pregnancy at or beyond 37 weeks, vertex presentation, live fetus, intact membranes with no vaginal bleeding were included. Women with previous caesarean section, APH and CPD were excluded from the study. 
In patients who were planned for induction, after taking written and informed consent, patients were asked to empty her bladder. Bishop score assessment was done one the day prior to induction. The cervical findings were recorded and bishop score was calculated according to the below mentioned modified bishop's score.

Table 1: Modified Bishop score.

\begin{tabular}{|llll|}
\hline Factors & 0 & 1 & 2 \\
\hline Dilatation & $<1.5$ & $1.5-3$ & $>3$ \\
\hline Station & -2 & -1 & 0 \\
\hline Position & Posterior & Middle & Anterior \\
\hline Effacement & 1.5 or more & Intermediate & 0.5 or less \\
\hline Consistency & Firm & Intermediate & Soft \\
\hline
\end{tabular}

Cervical assessment by ultrasound such as cervical length and cervical gland area was also done one day prior to induction. The probe was placed in the vagina proximal to the cervix to avoid cervical distortion. The entire endocervical canal was visualized in the sagittal plane. The distance between internal and external os was measured. The bishop's score was blinded to the doctor assessing cervical assessment. For cervical gland thickness, the entire endocervical canal was visualized in the sagittal plane. Cervical gland area is identified which is hypoechoic different from the uterine cervix stroma located around the endocervical canal and would correspond to the endocervical crypts area and measured in its entire thickness including the endocervical canal in $\mathrm{mm}$.

Induction was with $0.5 \mathrm{mg}$ of PGE2 gel was instilled intracervically. Patient was reassessed after every 8 hours and if she did not exhibit regular uterine contraction and cervical changes, PGE2 gel $2^{\text {nd }}$ and $3^{\text {rd }}$ dose was instilled accordingly. Maximum 3 inductions were carried out over a period of 24 hours. Primary outcome of the study was the onset of active labour i.e onset of regular uterine contractions and cervical dilatation of $3 \mathrm{~cm}$ or more.

Statistical package for the social science (SPSS for windows 10) was used for the data compilation and statistical analysis. The categorical data was analyzed using chi square or fischer exact test. Results were considered significant when $\mathrm{p}$ value was less than or equal to 0.05 for any of the test used. Receiver operating characteristic curve was use to analyzed the predictor of cervical maturation.

\section{RESULTS}

Total number of case studied were 180, all patients were induced according to the protocol after assessing the cervical status by trans-vaginal ultrasound and by bishop score.

Parity distribution in Table 3, 180 women was enrolled in the study but number of cases analysed were 160 as 20 women went on to have LSCS in latent phase of labor due to other reasons.

Table 2: Age distribution of study population.

\begin{tabular}{|ll|}
\hline Age & $\mathbf{N}=180$ \\
\hline $20-25$ & $60(33.3 \%)$ \\
\hline $26-34$ & $90(50 \%)$ \\
\hline$>35$ & $30(16.6 \%)$ \\
\hline
\end{tabular}

Table 3: Parity distribution of study population.

\begin{tabular}{|llll|}
\hline Gravida & $\mathbf{N}=160$ & $\begin{array}{l}\text { Active labor } \\
\mathbf{N}=124\end{array}$ & $\begin{array}{l}\text { Failed induction } \\
\mathbf{N}=36\end{array}$ \\
\hline Primi & 110 & $76(69 \%)$ & $34(31 \%)$ \\
\hline Multi & 50 & $48(96 \%)$ & $02(4 \%)$ \\
\hline
\end{tabular}

Table 4: Observation of result in comparison of cervical gland area and response to induction.

\begin{tabular}{|c|c|c|c|c|}
\hline $\begin{array}{l}\text { Cervical } \\
\text { gland area } \\
\mathbf{N}=160\end{array}$ & $\begin{array}{l}>\mathbf{3 m m} \\
\mathrm{N}=\mathbf{3 7}\end{array}$ & $\begin{array}{l}3-2 \\
N=58\end{array}$ & $\begin{array}{l}<2 \mathrm{~mm} \\
\mathrm{~N}=35\end{array}$ & $\begin{array}{l}\text { Absent } \\
\mathbf{N}=\mathbf{3 0}\end{array}$ \\
\hline $\begin{array}{l}\text { Active } \\
\text { phase } \\
\mathrm{N}=124\end{array}$ & $13(35 \%)$ & $46(80 \%)$ & 35 (100) & $30(100)$ \\
\hline $\begin{array}{l}\text { Failed } \\
\text { induction } \\
\mathrm{N}=36\end{array}$ & $24(65 \%)$ & $12(20 \%)$ & 0 & 0 \\
\hline
\end{tabular}

Out of 160 patients, 35 had cervical gland area less than 2 $\mathrm{mm}$ and 30 had absent CGA of which none had failed induction. When CGA was > $3 \mathrm{~mm}$ in 37 patients 24 (65\%) had failed induction and 13 (35\%) entered into active phase. This result shows the cervical gland area has significant role in predicting outcome of labor, absence of CGA greater is the incidence of successful labor induction.

Table 5: Observation of result in comparison of cervical length and response to induction.

\begin{tabular}{|llll|}
\hline $\begin{array}{l}\text { Cervical } \\
\text { length } \\
\mathrm{N}=160\end{array}$ & $\begin{array}{l}3 \mathrm{~cm} \\
\mathrm{~N}=\mathbf{4 8}\end{array}$ & $\begin{array}{l}3-2 \mathrm{~cm} \\
\mathrm{~N}=98\end{array}$ & $\begin{array}{l}<2 \mathrm{~cm} \\
\mathrm{~N}=14\end{array}$ \\
\hline $\begin{array}{l}\text { Active phase } \\
\mathrm{N}=124\end{array}$ & $20(40 \%)$ & $90(87.7 \%)$ & $14(100)$ \\
\hline $\begin{array}{l}\text { Failed } \\
\text { induction } \\
\mathrm{N}=36\end{array}$ & $28(60 \%)$ & $08(12.3 \%)$ & 0 \\
\hline $\mathrm{P}$ value $<0.001$ & & & \\
\hline
\end{tabular}

Out of 160 patients, 14 had cervical length less than 2 $\mathrm{cm}$ out of which none had failed induction, when cervical length was between 3 to $2 \mathrm{~cm}$ in 98 patients only 8 $(12.3 \%)$ had failed induction and $90(87.7 \%)$ of them entered into active phase. This result shows the sonographic assessment of cervical length has significant 
role in predicting outcome of labor, shorter the cervical length greater is the incidence of success of labor induction.

Table 6: Observation of results in comparison of cervical gland area and bishop score.

\begin{tabular}{|c|c|c|c|c|}
\hline $\begin{array}{l}\text { Cervical } \\
\text { gland area } \\
\mathbf{n = 1 8 0}\end{array}$ & $\begin{array}{l}>3 \mathrm{~mm} \\
\mathrm{n}=43\end{array}$ & $\begin{array}{l}3-2 \mathrm{~mm} \\
\mathrm{~N}=62\end{array}$ & $\begin{array}{l}<2 \mathrm{~mm} \\
\mathrm{n}=33\end{array}$ & $\begin{array}{l}\text { Absent } \\
\mathbf{N}=42\end{array}$ \\
\hline $\begin{array}{l}\text { Bishop } \\
\text { score <4 } \\
N=45\end{array}$ & $33(76 \%)$ & $12(20)$ & 0 & 0 \\
\hline $\begin{array}{l}\text { Bishop } \\
\text { score }>4 \\
N=135\end{array}$ & $10(24 \%)$ & $50(80 \%)$ & $33(100)$ & $42(100)$ \\
\hline
\end{tabular}

$\mathrm{P}$ value $<0.001$

Out of 180 patients, when CGA was $<2 \mathrm{~mm} \mathrm{(33)}$ and absent (42) all had Bishop score more than 4. When CGA was $>3 \mathrm{~mm}$ in 43 only $10(24 \%)$ had Bishop score more than 4 and $33(76 \%)$ had Bishop score less than 4.This result shows that CGA is a good predictor of cervical maturation.

Table 7: Observation of result in comparison of cervical length and bishop score.

\begin{tabular}{|lll|l|}
\hline $\begin{array}{l}\text { Cervical length } \\
n=180\end{array}$ & $\begin{array}{l}>3 \mathrm{~cm} \\
\mathrm{n}=58\end{array}$ & $\begin{array}{l}3-2 \mathrm{~cm} \\
\mathrm{n}=108\end{array}$ & $\begin{array}{l}<2 \mathrm{~cm} \\
\mathrm{n}=14\end{array}$ \\
\hline $\begin{array}{l}\text { Bishop score }< \\
4 \mathrm{n}=45\end{array}$ & $33(60 \%)$ & $12(20 \%)$ & 0 \\
\hline $\begin{array}{l}\text { Bishop score }>4 \\
\mathrm{n}=135\end{array}$ & $25(40 \%)$ & $96(80 \%)$ & $14(100)$ \\
\hline $\mathrm{P}$ value $<0.001$. & & & \\
\hline
\end{tabular}

Out of 180 patients, when CL was less than $2 \mathrm{~cm}$ (14) all had Bishop score $>4$. When CL was more than $3 \mathrm{~cm} \mathrm{(58,}$ $33(60 \%)$ had Bishop score less than 4 and $25(40 \%)$ had Bishop score greater than 4 . This result shows that CL is a good predictor of cervical maturation.

\section{DISCUSSION}

Labor induction is a day to day procedure in modern obstetrics. It is gaining even more importance when it comes to terminate pregnancies which have one or more risk factors where it is not preferred to wait till term for example in pre-eclampsia, intrauterine growth restriction, oligohydramnios etc. This is important not only for the obstetrician who is managing the case but also for the patient and her relatives who are giving consent to undergo the process of induction. They need to be explained the chances of failure of procedure, need for reinduction and need for operative delivery in cases of failed induction.

Cervical assessment was first described by bishop's score in 1964 and in most of the units cervix is assessed digitally prior to induction. Various modifications of bishop score but in spite of being the most widely used method for cervical assessment; bishop score has a number of drawbacks which has generated the need to develop a better system that is more objective and reproducible. The main drawback is that it is highly subjective and has shown that it is a poor predictor of labor induction outcome. Also the length of the cervix cannot be measured precisely by digital examination and other parameters that are included in the assessment such as consistency and position of the cervix are to some extent subjective and impressive. In addition to its subjectivity bishop score has wide inter and intra observer variation. ${ }^{3,9,10}$

Our study showed that sonographic assessment of cervical length and CGA successfully predicted cervical maturation. Ultrasound has specific advantages over bishop score. It causes less discomfort for the patient. It can assess full cervical length and status of internal os without invading endocervical canal and hence is less invasive, it is more objective and findings can be documented by taking a picture, also the findings are reproducible other coexisting finding like compound presentation and occult chord presentation if present can be documented which can be easily missed by doing just a digital examination.

Many studies mentioned have evaluated and compared cervical length against bishop's score and found both positive and negative results in term of cervical length being better prediction for successful induction as compared to bishop's score. Most of these studies on CGA had been done on patients with preterm labor or as a predictor for preterm labor. ${ }^{24,25,26}$

No studies are there at present to compare CGA in term patients to predict successful labor induction. Ana M Gomez Laencina compared the capacity of bishop's score and trans-vaginal sonographic cervical length for predicting successful induction of labor. The best cut off points for predicting successful induction were $24 \mathrm{~mm}$ for CL and 4 for Bishop score. In our study, CL less than 2 $\mathrm{mm}$ was comparable to Bishop score $>4$ in predicting onset of active labor. Pandis $G$ et al in a multicentric study undertaken in 240 women undergoing induction of labor, cervical length by ultrasound was compared with bishop's score in the prediction of successful vaginal delivery. ${ }^{12}$ In a similar study by Vonda ware concluded that both bishop score and cervical length showed linear co- relation with duration. ${ }^{13}$

In a study by Sekiya $\mathrm{T}$ et al evaluated the role of CGA during pregnancy in the assessment of cervical maturation at 16 to 41 weeks of gestation. ${ }^{4}$ Highly significant correlation were noted between the detection rate of cervical gland area and cervical length, cervical gland area and cervical maturation index. Cervical length was significantly shorter in the absence of CGA. 
Watson et al evaluated the 5 components of bishop's score, maternal parity and trans-vaginal ultrasound assessment of cervical length using a multiple regression curve. $^{14}$

In a study by Pires CR et al in conducted a prospective cohort study of 338 uncomplicated pregnancies was evaluated by trans-vaginal sonography between 21 and 24 weeks of gestation. ${ }^{5}$ They concluded that CL less than $2 \mathrm{~cm}$ and non-detection of CGA showed a strong association with preterm delivery. The result seems to indicate that absence of CGA can be new and important ultrasound marker for cervical maturation.

In our study significance of CGA was evaluated in term pregnancy and found that absence of CGA was associated with successful labor induction. Therefore indicating more favorable the cervix when CGA was absent and we evaluated the sonographic assessment of cervical length found that the cervical length less than $2 \mathrm{~cm}$ was associated with successful induction with sensitivity of 89 percent and specificity of 75 percent.

\section{CONCLUSION}

Sonograhically detected cervical gland area and cervical length was evaluated in predicting response to induction. Maximum number of successful induction is seen in the age group of 20-30 years. Also multigravida had significantly high number of successful induction. Cervical length when measured by USG revealed that shorter cervical length was associated with greater incidence of successful labor induction. There was no failed induction in subgroup of cervical length less than 2 $\mathrm{cm}$ obtained by USG. CGA when measured by USG revealed that absence of CGA was associated with greater incidence of successful labor induction. There was no failed induction when CGA was absent and less than 2 $\mathrm{mm}$. Bishop score was greater than 4 when cervical gland area was absent and $<2 \mathrm{~mm}$ and when CL was less than $2 \mathrm{~cm}$. This shows the absence of CGA and shorter CL are good predictors of successful induction. CL was less than $2 \mathrm{~cm}$ in 14 patients all have absence of CGA. This results shows the CL and CGA are good predictors of cervical maturation.

\section{Funding: No funding sources}

Conflict of interest: None declared

Ethical approval: The study was approved by the Institutional Ethics Committee

\section{REFERENCES}

1. Leppert PC, Woessner JF. The collegenous tissues of the cervix during labor and delivery. The extracellular matrix of the uterus, cervix and the fetal membranes. Publisher: Ithaca, NY: perinatalogy Press; 1991:68-76.

2. Httfield AS. Sonographic cervical assessment to predict the success of induction of labor; a systematic review with media analysis. Am J Obstet Gynecol. 2007;197(2);186-92.

3. Jackson GM, Ludmir J, Bader TJ. The accuracy of digital examination and ultrasound in the evaluation of cervical lenght. Obstet Gynecol. 1992;79:214-8.

4. Sekiya T, Ishihara K, Yoshimatsu K, Fukami T, Kikuchi S, Araki T, et al. Detection of cervical gland area during pregnancy by trans-vaginal sonography in the assessment of cervical maturation . Ultrasound Obstet Gynecol. 1998;12(5):328-33.

5. Pires CR, Moron AF, Mattar R, Diniz AL, Andrade SG, Bussamra LC, et al. Cervical gland area as an ultrasonographic marker for preterm delivery. International J Obstet Gynecol. 2006:93(3):214-9.

6. Saanchez-Ramos L, Delke. Induction of labour and pregnancy termination for fetal anomaly. James DK, Steer PJ, Weiner CP, Gonik B. High risk pregnancy management options, $3^{\text {rd }}$ ed. London: W.B. Saunders; 2006;1392-495.

7. Arulkumaran S, Gibb DM, TambyRaja RL, Heng SH, Ratnam SS, et al. Failed induction of labour. Aust NZ J Obstet Gynecol. 1985;25:190-3.

8. Scheerer LJ. Ultrasound evaluation of the cervix. Callen Ultrasonography in Obstetrics and Gynecology, $4^{\text {th }}$ edition. London W. B. Saunders; 2000:577-96.

9. Kushnir O, Vigil DA, Izquierdo L, Schiff M, Curet LB. Vaginal ultrasonograghic assessment of cervical length changes during normal pregnancy. Am J Obstet Gynecol. 1994;162:991-3.

10. Harrison RF. Assessment of factors constituting an inducibility profile. Obstet Gynecol. 1977;49:270-4.

11. Laecina AMG. Comparison of ultrasonographic cervical length and bishops score in predicting successful labor induction. Ata Obstetrician Gynecologician. 2007;86:799-804.

12. Pandis G, Papageorghiou AT, Ramanathan VG, Thompson MO, Nicolaides $\mathrm{KH}$, et al. Pre induction sonographic measurement of cervical length in the prediction of successful induction of labour. Ultrasound Obstet Gynecol. 2001;18:623-8.

13. Vonda ware. Trans-vaginal ultrasonographic cervical measurement as a predictor of successful labour induction. Am J Obstet Gynecol. 2000;182:1030-2.

14. Watson WJ, Stevens D, Welter S, Day D. Factors predicting successful labour induction. Obstet Gynecol. 1996:88(6):990-2.

15. Oxorn $H$. Uterus and vagina. Human labour and birth and , $5^{\text {th }}$ ed. New York: McGraw; 2000:17-22.

16. Cunningham FG, Leveno KG, Bloom SL. William's Obstetrics. $23^{\text {rd }}$ ed. New York: McGraw Hill; 2010:136-73.

17. Hadi H. Cervical ripening and labour induction; Clinical guidelines. Clin Obstet and Gynecol. 2000;43:524-36.

18. Nambiar J. Induction of labour. Obstetrics and Gynecology for post graduates by SS Ratnam K Bhaskar Rao and Sabathan Arulkumaran, $3^{\text {rd }}$ ed. Universities Press. 2004;1:364-72. 
19. Roman H, Verspyck E, Vercoustre L, Degre S, Col JY, Firmin JM, et al. Does ultrasound examination when cervix is unfavourable improve the prediction of failed induction. Ultrasound Obstet Gynecol. 2004;23:357-66.

20. Ware V, Raynor B. Transvaginal ultrasonographic cervical measurement as a predictor of successful induction of labour. Am J Obstet Gynecol. 2000:182;1030-2.

21. Chandra, Crane JM, Hutchens D, Young DC, et al. Transvaginal sonographic and digital examination in predicting successful labor induction. Obstet Gynecol. 2001;98;2-6.

22. Tan PC, Vallikkannu N, Suguna S, Quek KF, Hassan J. Transvaginal sonographic measurement of cervical length vs Bishop score in labour induction at term :tolerability and prediction of cesarean delivery . Ultrasound Obstet Gynecol. 2007;86:799-804.

23. Asakura H, Fukami T, Kurashina R, Tateyama N, Doi D, Takeshita T. Significance of cervical gland area in predicting preterm delivery birth for patients with the threatened preterm delivery. Comparison $\mathrm{CL}$ and the fetal fibronectin. Gynecol Obstet Invest. 2009;68:1-8.

24. Grgic O, Matijevic R, Vasilj O. Qualitative glandular cervical score as potential new sonomorphological parameters in screening for preterm delivery. Ultrasound in Medicine and Biology. 2006;32(3):333-8.
25. Yoshimatsu K, Sekiya T, Ishihara K, Fukami T, Otabe T, Araki T. Detection of the cervical gland area in threatened preterm labour using transvaginal sonography in the assessment of cervical maturation and pregnancy outcome. Gynecol Obstet Invest. 2005;53:149-59.

26. Nishida N, Fukami T, Asakura H, Takeshita T. Significance of absent cervical gland area in prediction for preterm delivery: comparison of predictive efficacy with short cervix and positive fetal fibronectin. Ultrasound in Obstet and Gynecol. 2008;32:243-307.

27. Gopalan S, Jain V. Induction of labour. Mudaliar and Menon's clinical Obstetrics, $10^{\text {th }}$ edition, Orient Longman; 2005:357-362.

28. Vrouenracte FP, Roumen FJ, Dehing CJ, van den Akker ES, Aarts MJ, Scheve EJ. Bishop score and risk of cesarean delivery after induction of labour in nulliparous women. Obstet Gynecol. 2005;105:6907.

29. Flatin Traub EF, Boulvain M, Faltin DL, Extermann $\mathrm{P}$, Irion O. Reliability of Bishop score before labour induction at term. Eur J Gynecol Reprod Biol. 2004;112:178-81.

30. Novakov Mikic, Ivanović L, Dukanac J. Transvaginal sonography of uterine cervix in prediction of the outcome labour induction. Med Pregl. 2000;53:569-78.

Cite this article as: Savitha C, Arpitha VJ,

Nagarathnamma R. Significance of cervical length and cervical gland area in cervical maturation. Int $\mathrm{J}$ Reprod Contracept Obstet Gynecol 2016;5:2634-9. 